\title{
Laudacja \\ z okazji nadania Pani Jolancie Wadowskiej-Król godności Doktora Honoris Causa Uniwersytetu Śląskiego
}

Pani Jolanta Wadowska-Król poprzez swoje obywatelskie działanie, osobistą odwagę i poświęcenie pokazała nam wszystkim, jak wiele może osiągnąć człowiek - działający nawet samotnie - w dobrej sprawie. Wiemy z naszej historii, jak trudno oprzeć się potężnym, przeważającym siłom. Zwłaszcza dzieje naszego regionu zawierają w sobie wiele takich sytuacji: dramatycznych wyborów jednostki, postawionej wobec nieprzyjaciół wolności, podmiotowości człowieka; rzadko są to historie o pozytywnym zakończeniu. Nauczyliśmy się szacunku dla złożoności i dramatu takich wyborów, ponieważ ludzie tej ziemi musieli zbyt często wybierać między osobistymi przekonaniami, wolnością a na przykład obowiązkiem ochrony życia swojej rodziny i bliskich.

Tym większą radość przynosi nam dzisiejszy dzień, w którym oddajemy sprawiedliwość Doktor Jolancie Wadowskiej-Król - osobie, która w imię najwyższych wartości oraz swojej przysięgi lekarza stanęła samotnie naprzeciw całej machiny partyjnej i państwowej. Również inne regiony Polski poznały ciężar tej machiny; na Śląsku, bezlitośnie eksploatowanym gospodarczo i ekologicznie, ale dostarczającym węgla, stali i pieniędzy w obcych walutach, tak cennych dla ówczesnej władzy, ciężar ten był szczególny, a wymagane posłu- 
szeństwo i kary - bezwzględne. Bunt Pani Doktor Wadowskiej-Król był więc dla opresyjnej władzy i jej legitymizacji znaczący.

Profesor Maria Ossowska, pisząc w ciężkich latach 50. dzieło o demokracji, stwierdziła, że potrzebuje ona wzorców osobowych - i że każda epoka historyczna takich wzorców potrzebowała. W średniowieczu był to rycerz lub ascetyczny święty wyrzekający się świata, w okresie odrodzenia - kupiec-odkrywca oraz artysta wskrzeszający świetność sztuki starożytnej. W późniejszym czasie zdobywca, żołnierz, a w XIX wieku - wynalazca i przedsiębiorca.

Kto ma być naszym wzorem dzisiaj? W epoce, gdy najwspanialszymi budowlami miast nie są już katedry, uniwersytety i ratusze, ale siedziby banków i międzynarodowych korporacji, jednym $\mathrm{z}$ takich nowych wzorów staje się człowiek nauki, ale taki, który w swoich badaniach jest uczciwy bez względu na konsekwencje, bezstronny, walczący o prawdę. Są wśród owych ludzi nauki tacy, którzy walczą dziś ze śmiercionośnym wirusem SARS-CoV-2, tacy, którzy dzięki wytyczaniu nowych granic elektromobilności uwalniają nas od świata spalin, a wreszcie tacy, którzy przez badania humanistyczne starają się, aby nasza prywatność i wolna wola przetrwały epokę micro-targetingu oraz profilowania społecznego, stosowanego na masową skalę $\mathrm{w}$ celu agresywnej dezinformacji i manipulacji. Dla nich wszystkich, $\mathrm{z}$ różnych powodów, prawdziwym wzorem może być Pani Wadowska-Król, przyjmowana dziś jako Doktor Honoris Causa na zawsze do społeczności Uniwersytetu Śląskiego.

Wymienić można sześć powodów, dla których może być Ona takim wzorem dla nowych pokoleń naukowców i studentów.

Po pierwsze - Jej życie pokazuje, że wolne, niezależne badania naukowe mają sens i mogą prowadzić do przełomowych, w skali społecznej, rezultatów. Należy mieć odwagę badawczą.

Po drugie - zdobywanie stopni i tytułów naukowych, rankingi i punktacje, w które została obecnie wtłoczona kariera naukowa, powinny być środkiem, a nie celem. Jeśli wymagają tego prawda i nasze posłannictwo, warto rozstać się również z formalną karierą naukową. Warto być przyzwoitym, choć, jak podkreślał Władysław Bartoszewski, nie zawsze się to opłaca.

Po trzecie - rzetelne badania naukowe powinny odbywać się w poszanowaniu godności człowieka i jego podstawowych praw. Badacz nie powinien służyć 
„nauce zdeprawowanej”, dążącej do zniewolenia człowieka. Także nauka, jak wiemy z historii, może efektywnie służyć „siłom ciemności”.

Po czwarte - nawet samotna misja w walce o prawdę nie przebiega w próżni społecznej, a zaufanie społeczne wzmacnia jej rezultaty. Przez lata wytrwałej pracy u podstaw, dla dobra całej społeczności Pani Doktor zdobyła zaufanie społeczne mieszkańców Szopienic, a to umożliwiło Jej ostatecznie przeprowadzenie w ukryciu tak rozległych badań. Zawdzięczała to również pomocy i odwadze pielęgniarki - Pani Wiesławy Wilczek, także cieszącej się ogromnym poważaniem środowiska lokalnego.

Po piąte - naukowiec zgodnie ze swoim sumieniem musi udostępniać wyniki swoich badań, ostrzegać o zagrożeniach, które dostrzega, bez względu na konsekwencje.

Po szóste - cechą prawdziwego naukowca jest zdolność dzielenia się swoją wiedzą, jeśli inna osoba ma większe szanse na upowszechnienie jej dla dobra wspólnego. Tak uczyniła dla dobra sprawy Pani Wadowska-Król.

Nowa Doktor Honoris Causa Uniwersytetu Śląskiego należy do tak poszukiwanych przez media „autorytetów naszych czasów”. Uniwersytet, mimo wielu współczesnych, biurokratycznych, centralistycznych przekształceń, taką wspólnotą pozostaje, jest naszą uczelnią macierzystą - Alma Mater. To również moja uczelnia macierzysta, z której jestem dumna. Ma dawać studentom oparcie i wzór odniesienia - także wtedy, kiedy z przyczyn zawodowych przyjdzie w waszym życiu, drodzy studenci i doktoranci, członkowie wspólnoty Uniwersytetu, czas trudnych wyborów, możecie znaleźć oparcie w trafnych, ale trudnych decyzjach waszych poprzedników.

Na szczycie wspólnoty uczących się i nauczających znajdują się według starej tradycji uniwersyteckiej Doktorzy Honoris Causa. Z jednej strony nadanie tej godności jest wyrazem czci i hołdu wszystkich instytutów, wydziałów i innych jednostek Uniwersytetu, uchwałę podejmuje bowiem Senat w imieniu całej społeczności akademickiej, z drugiej - nadanie godności Doktora Honoris Causa podlega ścisłym rygorom akademickim, ze starannym wyborem recenzentów, którzy poddają szczegółowej analizie sylwetkę i dorobek kandydata.

Wielokrotnie obserwujemy w mediach drukowanych i elektronicznych zwyczajowe narzekanie - po pierwsze, na brak autorytetów, po drugie, na obojętność młodego pokolenia wobec autorytetów. Czytamy o znudzeniu i odrzucaniu 
postawy heroicznej, o tym, że największymi wzorami stają się youtuberzy i patostreamerzy, kucharze i aktorzy. Można oczywiście przypomnieć za Seneką, że społeczeństwa, w których największymi bohaterami zdają się aktor i kucharz, to te, które wchodzą w fazę dekadencji. Można przypomnieć, że żyjemy w czasach, w których święte niegdyś pojęcia, jak odwaga, przyjaźń i wolność, stają się nazwą lub elementem reklamy artykułów higienicznych, słodyczy, produktów bankowych, ale tego typu narzekania są tak stare, jak historia cywilizacji, i bezproduktywne. Często są także fałszywe.

Jak ważną historyczną lekcję stanowią dla nas formułowane niemal w przeddzień drugiej wojny światowej skargi na bezideowość młodego pokolenia! Dziś wiemy, że dotyczyły one heroicznego pokolenia Kolumbów. Dlatego jestem głęboko przekonana, że również młodzi uczestnicy naszej uroczystości, kiedy przyjdzie dla nich godzina próby, a w Polsce przychodzi ona prawie dla każdego pokolenia, zadziwią nas swoją odwagą i ideowością. Wyrazi się ona zupełnie inaczej, niż to sobie dzisiaj wyobrażamy, ale zapewne nastąpi; są już pierwsze choć jeszcze słabe - oznaki rosnącego nowego idealizmu młodego, urodzonego w czasach wolności pokolenia. Oczekujemy tego z nadzieją.

Recenzenci w przewodzie doktorskim o nadanie tytułu Doktora Honoris Causa omawiają wiele aspektów działalności Pani Jolanty Wadowskiej-Król, nie jest więc uzasadnione powtarzanie ich w niniejszej laudacji. Chcę jednak zwrócić uwagę na dwa $\mathrm{z}$ nich, szczególnie nam dzisiaj potrzebne: jest to, po pierwsze - odwaga cywilna, a po drugie - odporność na to, co współcześnie najczęściej nazywamy potocznie „hejtem”. Trudno przecież wyobrazić sobie szlachetniejsze działanie, niż to, które przyczyniło się do uratowania 2 tys. dzieci i wyburzenia najsilniej skażonych domów Szopienic, ale również wtedy pojawili się nienawistnicy, którzy posądzali o wyłudzanie mieszkań oraz odszkodowań dla chorych na ołowicę. To nie złamało jednak Pani Doktor Wadowskiej-Król, a Jej odwaga cywilna lśni szczególnie silnym blaskiem w zestawieniu ze strachem innych. Strachem, który doprowadził do takiego utajnienia treści Jej doktoratu, że Rada Instytutu przyjęła rozprawę do dalszej realizacji tylko na podstawie tytułu, ale nawet $\mathrm{w}$ tej ściśle utajnionej pracy doktorskiej nakazano Autorce usunąć dane wskazujące na zatrucie ołowiem. Trudno także napisać rozprawę doktorską na temat ołowicy, skoro zabraniano Doktorantce użycia w niej słowa „ołowica”. Przypomina to problemy walki z cenzurą w bliskiej 
mi dyscyplinie naukowej, w której trudno było pisać prace o samorządzie terytorialnym, skoro zakazano używania tego pojęcia. Symptomatyczne były też ówczesne - niepodpisane - recenzje profesorów medycyny, gdzie negatywna ocena dotyczyła z kolei przymusowo usuniętych z rozprawy wyników. Wiele to mówi o problemie odwagi cywilnej w nauce i skutkach jej braku. Naszej refleksji w tym dniu wymaga również brak skruchy konkretnych sprawców tej krzywdy - ich nazwiska zostaną zapamiętane jako ostrzeżenie przydatne także w naszych czasach, w których nie brak trudnych wyborów.

Jaką korzyść możemy wynieść $\mathrm{z}$ tej historii dla naszych życiowych wyborów? Po pierwsze, że odporność na dezinformację, spokojne przeciwstawienie się zawiści i małości ludzkiej jest warunkiem niezbędnym do spełnienia życiowych zadań, że nie powinno to podważać $\mathrm{w}$ nas determinacji i wiary we własne siły. Po drugie, że odwaga cywilna bywa czymś nawet większym niż odwaga na polu walki, nie jest to bowiem jednorazowy zryw, chwila przełamania się, ale lata znoszenia upokorzeń i przeciwności dla służenia dobru wspólnemu. Równocześnie trwanie przy dobrych czynach, niezależnie od pomówień i wrogości, wydaje w końcu trwałe owoce i to one są w istocie nagrodą.

Takich wielkich czynów rzadko dokonuje się jednak w samotności. Samotność wspomniana nie była na szczęście całkowita. Należy przypomnieć z wdzięcznością tych, którzy byli poprzednikami lub towarzyszyli naszej nowej Doktor Honoris Causa w Jej drodze - byli to: Doktor Edward Gryglewski, Profesor Bożena Hager-Małecka oraz wspomniana już Wiesława Wilczek. Ich zasługi to trzecia wskazówka dla nas - społeczności akademickiej XXI wieku. W dążeniu do naprawy zła i poprawy świata - czy chodzi o kryzys klimatyczny, czy o restrukturyzację społeczno-gospodarczą Śląska, czy o nowe odkrycia z zakresu fizyki i chemii - warto liczyć się z poprzednikami, szukać przyjaźni i wsparcia w realizacji swojej misji.

Droga, która doprowadziła nas do dzisiejszej uroczystości, dotyczy tylko jednego z rodzajów skażeń chemicznych - choć szczególnie niebezpiecznego $\mathrm{z}$ występujących przez dziesiątki lat w naszym regionie. Stanowi jedynie wycinek cierpienia ludności naszego województwa, która płaciła latami swoim zdrowiem i życiem za wydobycie węgla, a także za sprawą hutnictwa żelaza i metali nieżelaznych. Aby usunąć skutki tylko na małym terenie huty Szopienice, trzeba było usunąć 200 tys. ton skażonej, zatrutej ziemi. 
Mam nadzieję, że dzisiejsza uroczystość nie jest końcem drogi, a jej początkiem w oddawaniu sprawiedliwości mieszkańcom Górnego Śląska, początkiem położenia kresu krzywdzie społecznej i ekologicznej. To nie jest bowiem jakaś dawna historia ze szczęśliwym happy endem. Nasze miasta nadal zajmują czołowe miejsca pod względem zanieczyszczenia powietrza, nie tylko w skali europejskiej, ale także światowej. Straszliwe choroby z tym związane dotyczą zwłaszcza dzieci i osób starszych - są to szczególnie choroby nowotworowe, serca, uszkodzenia mózgu u dzieci. Należy podkreślić, że wciąż nie ma powszechnego obowiązku badań przesiewowych noworodków i dzieci szkolnych w kierunku skażeń toksykologicznych. Fakty bowiem są nieubłagane - obecnie do najbardziej zanieczyszczonych miast UE należą takie śląskie miasta, jak: Pszczyna, Rybnik, Żywiec. Na czarnej liście nadal znajdują się Katowice.

Pani Doktor Wadowska-Król dała nam przykład i dodała odwagi, ale Śląsk o czystym powietrzu i nieskażonej ziemi to cel i zadanie tego i przyszłego pokolenia. Mam nadzieję, że wszyscy, którzy dzisiaj słuchają tych słów, czują się do tej walki wysoce zmotywowani. Stawia to przed wszystkimi obecnymi wielkie lustro, ponieważ dramat trwa. Jaką rolę w nim gramy? Czy jesteśmy Panią Jolantą Wadowską-Król, czy „niepodpisanymi recenzentami”, czy też Rektorem ówczesnej Śląskiej Akademii Medycznej? To zależy tylko od nas.

Pani Doktor Jolanta Wadowska-Król potrafiła w pojedynkę osiągnąć tak wiele w skrajnie nieprzyjaznych warunkach. Od tego czasu minęły dziesiątki lat, dokonano przecież zmiany ustroju, ale światowe statystyki nie kłamią. Nasze zobowiązanie, zwłaszcza władzy centralnej, ale także samorządowców i wszystkich mieszkańców pozostaje - jest nadal ogromnym, niespłaconym długiem z przeszłości.

prof. dr hab. Irena Lipowicz Katedra Prawa Administracyjnego i Samorzadu Terytorialnego, Uniwersytet Kardynała Stefana Wyszyńskiego w Warszawie 